
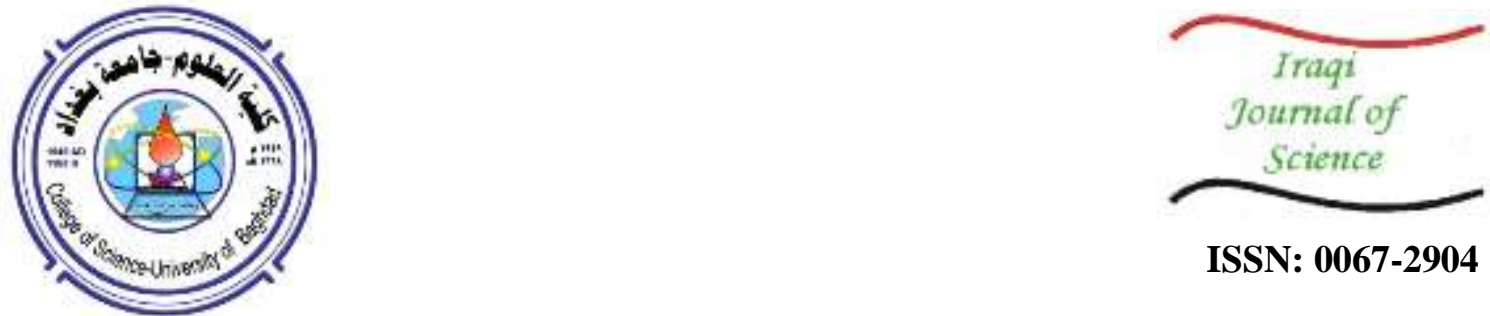

ISSN: 0067-2904

\title{
Determination of Lead Levels in Fuel Used for Vehicles in Baghdad City
}

\author{
Hassanein A. Hassoon \\ Department of Biology, College of Science, University of Baghdad, Baghdad, Iraq
}

Received: 30/6/2019

Accepted: $31 / 7 / 2019$

\begin{abstract}
The wide use of lead compounds as an engine anti-knock reflects conversely on all components of the ecosystem. This study aimed to detect the concentration of lead in various types of gasoline and gas oil that are highly consumed by vehicles. Eight fuel samples were collected from different feul stations distributed in different districts of Baghdad city. These included two gas oil (diesel) stations and three stations for each type of gasoline (leaded and unleaded). Lead was extracted by the modified chemical method, and then flame atomic absorption technique was applied to assay its concentrations. The results indicated that lead levels were within permitted limits $\left(150 \mathrm{mg} \mathrm{Lead} \mathrm{L}^{-1}\right)$ recommended by the international agencies. The highest lead mean concentration was $105 \mathrm{mg} / \mathrm{L}$, recorded in Latifiya leaded gasoline, whereas the lowest mean was $3.1 \mathrm{mg} / \mathrm{L}$ in unleaded gasoline imported from the United Arab Emirate. As for gas oil, lead concentration occurred within a mean of $1.85-2.05 \mathrm{mg} / \mathrm{L}$. The influence of some leaded gasoline improvements, octane booster and octane plus, was estimated, which revealed sharp declines in lead mean concentrationsto values of 1.05 and $5.2 \mathrm{mg} / \mathrm{L}$ for Latifiya and Rusafa gasoline, respectively. Furthermore, the daily lead emission was estimated for the registered vehicles in Baghdad and revealed a high concentration of $1837.7 \mu \mathrm{g} \mathrm{lead} \mathrm{m}^{-3}$ for private cars. This study proposes avoiding the addition of lead compounds to fuel, in order to reduce its adverse effects on general health, and raising the awareness of society to this problem.
\end{abstract}

Keywords: Fuel improvements, gasoline type, lead emission.

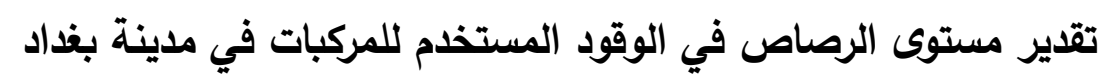

$$
\begin{aligned}
& \text { حسنين عبود حسون } \\
& \text { قسم علوم الحياة ، كليةالعلوم، جامعة بغداد، بغداد، العزاق لئول } \\
& \text { الخلاصة }
\end{aligned}
$$

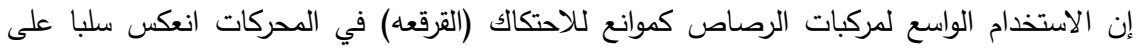

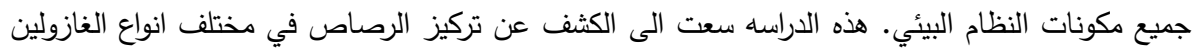

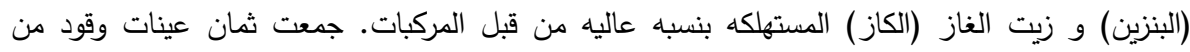

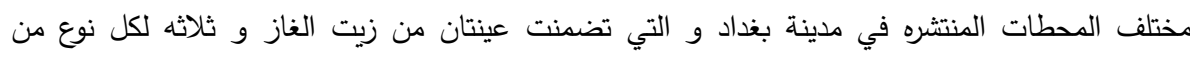

$$
\begin{aligned}
& \text { الغازولين بنوعيه (الحاوي و الخالي من الرصاص). تم استخلاص الرصاص بطريقه كيمياويه محوره و من ثم ثنائ }
\end{aligned}
$$

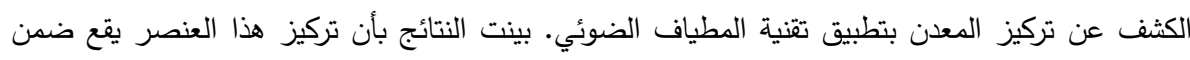

$$
\begin{aligned}
& \text { الحدود المسموح بها من قبل المنظمات العالميه 150غرام رصاص لكل لتر لتران أن أعلى متوسط تركيز } 105
\end{aligned}
$$

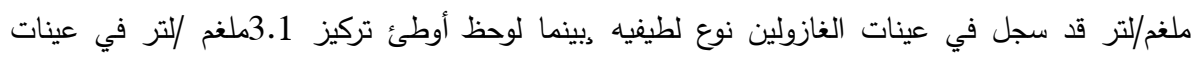

*Email: Hassanainabbood@yahoo.com 


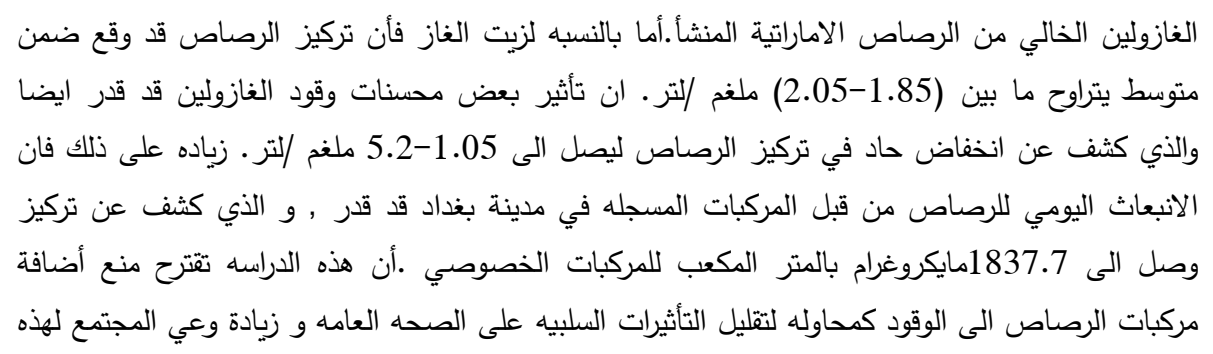

\section{Introduction}

Lead is a noxious element to human health and its compounds are known to cause prominent damage to the human being. Their widespread use was reported to cause many health issues that need to be remediated worldwide. Hazardous exposure to lead caused approximately 143000 death cases every year and is responsible for $0.6 \%$ of global burden of diseases [1]. Its adverse effects result from its ability to accumulate as a toxicant in multiple body systems which is attributed to disturbing many enzyme functions by interfering, blocking or preventing their incorporation with many vital elements such as iron [2].Children and pregnant women are estimated as more vulnerable groups to this heavy metal, indicated by high blood and bone levels [3]. Due to this pollution, damages in renal, nervous, gastrointestinal and cardiovascular systems might occur [1]. Nervous system damages manifest as adult memory loss, descending in children Intelligence Quotient (IQ) and acute encephalopathies such as congenital malformation [4]. For these reasons, WHO and US Center for Disease Control and Prevention (CDC) considered $\geq 10 \mu \mathrm{g} / \mathrm{dl}$ as an elevated blood level for adults [5]. A human lead level is an indicator that shows the degree of personal exposure through the life or at least the past three months related to seasonal consumption of fuel by vehicles [6]. California Air Resources Board [7] concluded that children at or above this level expressed a lower standard intelligence test resulted from neuro-developmental effect. Children are more vulnerable than adults due to several factors such as high assimilation rate in stomach, greater metabolic rate, more sensitive nervous system, greater amount of air (born lead) intake through the mouth, and the bad habit of hand - to -mouth contact which facilitates the intake of lead deposits on various surfaces[8]. Lead as a deposit heavy metal is found in different components of ecosystem such as water, soil and dust. It can enter the human body via inhalation, digestion of Lead-bearing particles and absorption through skin pathways.Moreover, malnutrition of iron, zinc, calcium, and phosphorus facilitate lead absorption [9]. Poisoning or intoxication occurs through the exposure to this metal or its chemicals. Rapid urbanization and industrialization play important roles in increasing exposure to this pollutant, due to more demand for energy that ultimately deteriorate urban air quality [10].Further attention is enforced to reduce the use of lead in petrol, paint, plumbing, and solder, leading to tangible reduction in lead levels despite of the remaining sources of exposure, particularly in developing countries [11]. Vehicle emissions are another remarkable source of lead, especially in the areas with high traffic intensity [4].World Health Organization (WHO) estimated about 1.9 billion humans suffering from health problems due to this source and called for switching off the use of leaded gasoline completely prior to 2001[8]. The importance of identifying or monitoring potentially hazardous elements in crude oil and regulating their residual abundance recently required a large attention [12]. In the past twenty-five years, researchers have been interested in examining lead concentration in leaded and unleaded petrol as different studies had shown that most of lead released to the atmosphere results from combustion of gasoline [13]. Lead additives include tetraethyl and, to some extent, tetramethyl lead (TEL and TML, respectively) which are added to the gasoline as anti-knocks; therefore, these additives were identified as the main source of lead exposure during filling vehicles or from their exhausters [11]. Gasoline complex structure of light hydrocarbons containing 5 to 11 carbon atoms and its boiling point that fluctuates between $15-190{ }^{\circ} \mathrm{C}$ enhances its fraction into light, medium and heavy naphtha in the atmosphere [14]. Anti-knocked products were first produced in 1921 by General Motors company, but they then phased out in 1970 due to their adverse effects on human health and ultimately banned in January 1995 [15]. Consequently, air lead levels of New York state declined from 0.93 in 1973 to 0.37 in 1983 and later to as low as $0.07 \mu \mathrm{g} / \mathrm{m}^{3}$ in 1993 , until they reached to $0.0047 \mu \mathrm{g} / \mathrm{m}^{3}$ in 2016 [16]. Similarly, the European Union and Canada restricted the use of lead in gasoline to $150 \mathrm{mg} / \mathrm{L}$, consistent with the WHO guideline for maximum lead content in petrol [8]. In addition, all newly 
manufactured vehicles should contain catalytic converters that obligate the use of unleaded fuel [17].Extended and exacerbated application of TEL and TML by refineries as a low cost method to improve octane number in gasoline caused an adverse outcome on vehicle emissions which became loaded with different heavy metals, especially lead [11].Several developing nations in the middle east are still using premium leaded fuel (PLF). In the recent years, however, leaded free gasoline (LFG) was introduced extensively in Iraqi markets. Hence, the parallel use of various types of fuel and the high traffic congestion could have serious consequences to environment and health, which are yet underestimated in research and policies.

Therefore, this study was carried out to compare leaded and unleaded fuel produced in Iraq,as well as other imported types, in an attempt to establish data that describe the current situation of pollution with this contaminant in Baghdad and to stimulate further related investigation in the future.

\section{Materials and Methods}

\section{Sampling sites}

Three labels of leaded gasoline, namely Latifiya, Doura, and Rusafa, were collected from three selected petrol - pumping stations in Baghdad city, namely Al-Wefaq, Al- Jauadian and Al-Kilani, respectively. Three labels of unleaded gasoline, namely Shuaiba (local product) and two labels imported from United Arab Emirate and Kuwait were collected from 3 main stations, namely AlSaadoun, Al-Rissalah, and Musa Bin Naseer, that represented the main suppliers of this type of gasoline. All these types of fuel are used in automobiles, 3 wheeler rickshaws, and motorcycles. Moreover, gasoil samples that are used in trucks and buses (diesel engines) were collected from two selected petrol stations of Al-Wefaq and Al-Bilad.

\section{Samples collection}

Eight samples were collected during 2017 from each of the above mentioned petrol pumping stations. Samples were filled to the upper end of brown glass bottles tightly sealed with teflon-lined screw caps. Any free spaces in collecting bottles were avoided to prevent any losses of organic compounds. After collecting samples, the bottles were appropriately labeled and refrigerated at $4^{\circ} \mathrm{C}$ until analysis [17].

\section{Preparation of samples}

Direct analysis of oil products is not the ideal method; these products contain a mixture of compounds that have a corrosive and deleterious effect on analytical instruments[18]. Therefore, the samples were treated with organic solvents at first in order to achieve a high precision analysis [19].Five $\mathrm{ml}$ from a sample was transferred to a $50 \mathrm{ml}$ volumetric flask, then $30 \mathrm{ml}$ of ethyl acetate was added, followed immediately by $0.1 \mathrm{ml}$ of $3 \%(\mathrm{w} / \mathrm{v})$ iodine in toluene. The mixture was left to react for $1 \mathrm{~min}$ andthen treated with $5 \mathrm{ml}$ of $1 \%(\mathrm{v} / \mathrm{v})$ tween 80 . Finally, the solution was completed with ethyl acetate to $50 \mathrm{ml}$ [17].

\section{Gasoline improvers}

Many additives to improve engine power have been introduced and distributed in the Iraqi markets. The most available types are octane booster and octane plus. The first is of an Iranian origin and is produced by Milad Pegah Co., whereas the other is a German product manufactured by Liqui Moly Co. Based on the manual of each product, $200 \mathrm{ml}$ of the improver was added to50 $\mathrm{L}$ of different leaded gasoline brands and left overnight to react, then a sample $(5 \mathrm{ml})$ was taken from each type and prepared according to the previous method.

\section{Heavy metal determination}

Flame atomic absorption spectrophotometer was used to determine lead concentration in gasoline (leaded and unleaded) and gasoil samples according to a previously described procedure [10].

\section{Calculation of lead emissions}

The following equation was applied to calculate the daily emissions of lead in $\mu \mathrm{g} / \mathrm{m}^{-3}$ from various vehicles, as described by Parekh et al. [17]:

Lead $=\mathrm{C} \times \mathrm{D} \times \mathrm{N} \times 10^{-6} / \mathrm{E}$

$\mathrm{N}=$ number of each registered vehicles (according to general traffic directorate index for year 2017)

$\mathrm{C}=$ Lead concentration in fuel types $(\mathrm{mg} / \mathrm{L})$

$\mathrm{D}=$ Crossing distance per day for each vehicle type $(\mathrm{Km})$

$\mathrm{E}=$ Distance $(\mathrm{Km})$ passed through consuming $1 \mathrm{~L}$ of fuel 


\section{Results and Discussion}

Table-1 shows the concentration of lead in leaded and unleaded fuel samples collected at the selected filling stations. The brands reported here might be typically representative for the entire gasoline supply from refineries to the city.

Table 1-Lead concentration in different commercial gasoline and gas oil samples marketed in Baghdad.

\begin{tabular}{|c|c|c|c|}
\hline \multirow{2}{*}{$\begin{array}{c}\text { Types of gasoline } \\
\text { (leaded fuel) }\end{array}$} & $\begin{array}{c}\text { Concentration of Pb } \\
\mathrm{mg} / \mathrm{L}\end{array}$ & $\begin{array}{c}\text { Types of gasoline } \\
\text { (unleaded fuel) }\end{array}$ & $\begin{array}{c}\text { Concentration of Pb } \\
\mathrm{mg} / \mathrm{L}\end{array}$ \\
\cline { 2 - 4 } & Mean \pm S.D. ${ }^{*}$ & Mean \pm S.D. ${ }^{*}$ \\
\hline Al. Doura & $100.00 \pm 14.14^{\mathrm{Aa}}$ & Shuaiba & $6.50 \pm 2.12^{\mathrm{Cd}}$ \\
\hline Latifiya & $105.00 \pm 7.07^{\mathrm{Aa}}$ & U.A.E & $3.10 \pm 0.14^{\mathrm{Cd}}$ \\
\hline Al. Rusafa & $55.00 \pm 7^{\mathrm{Ad}} \mathbf{7}^{\mathrm{Bb}}$ & Kuwait & $3.50 \pm 2.12^{\mathrm{Cd}}$ \\
\hline Diesel / Doura & $1.85 \pm 0.07^{\mathrm{Dc}}$ & Diesel / Latifiya & $2.05 \pm 0.07^{\mathrm{Dc}}$ \\
\hline
\end{tabular}

\footnotetext{
*Different uppercase letters: Significant difference $(\mathbf{P} \leq \mathbf{0 . 0 5})$ between means of columns. *Different lowercase letters: Significant difference $(\mathbf{P} \leq \mathbf{0 . 0 5})$ between means of rows.
}

The results demonstrate that lead was detected in all samples and its mean concentration varied. Lead concentrations in gasoil (diesel) were within a mean range of 1.85-2.05 $\mathrm{mg} / \mathrm{L}$ for samples collected from the two selected sampling stations. For leaded gasoline, samples collected from the three selected stations also showed levels that fell in a range of $55-105 \mathrm{mg} / \mathrm{L}$, whereas the three various samples of unleaded gasoline recorded lead concentration in the range of 3.1-6.5 mg/L. The results exhibited lower lead concentrations as compared with the study of Parekh et al. [17] in Karachi/Pakistan which reported higher concentrations (150-200 mg/L). Lead concentrations in the present study occurred within what was recommended by the International Union of Air Pollution Prevention Association for Calcutta/India [20, 21]. The present results are in agreement with those found by Mohammed et al. [11] who reported lead concentrations of $0.16-180 \mathrm{mg} / \mathrm{L}$ for various gasoline samples at Kurdistan region /Iraq. In contrast, lead content in lead-free gasoline is consistent with that indicated by Ryan [13] who pointed limits reached to $7 \mathrm{mg} / \mathrm{L}$ in the USA. The maximum lead concentration permitted by the U.S Federal Code Regulation to be added at refinery processes must not exceed $14 \mathrm{mg} / \mathrm{L}$ [8]. Accordingly, most of the samples in the present study contained lower lead concentration as compared to that limit, with the sample from the leaded brand Latifiya exceeding this limit (Table-1). In addition, the outcomes of this work are coincided with the standard limits proposed by the WHO (150 to $7 \mathrm{mg} / \mathrm{L}$ ) for leaded and unleaded fuel, respectively [11].

Recently, many commercial products have been distributed in Iraqi markets, underlying what is known as gasoline improvements. These products are commonly added to fuel in order to render it more suitable for all kinds of petrol engines by optimizing their performance, improving starting behavior, and ensuring smooth performance of the engine.

As shown in (Tables-2, 3) these products caused reductions in lead mean concentrations for those labels in comparison with its previous concentration. Various technological processes are available for octane enhancement other than the use of leaded additives. According to Magda [21], processes such as oxygenation and blending are used locally to improve stock gasoline by mixing it with methyl tertiary butyl ether (MTBE), ethyl tertiary butyl ether (ETBE), methanol and ethanol to produce an end product with a high octane value that meets the consumer desire.

As mentioned previously, modern vehicles are provided with a catalytic converter that regulates the emissions from tail pipe exhauster. It was found that gasoline with $125 \mathrm{mg} / \mathrm{L}$ lead or greater causes a phenomena known as lead poisoning, resulting from the adhesion of its particles on the catalytic chamber after only a few tank fillings. This issue was solved by adding only a small amount of lead of 
about $50 \mathrm{mg} / \mathrm{L}$ to gasoline, which was necessary to avoid such effect [8].The results in the present study revealed a less contentof lead in LFG as observed in Table-1.

Table 2-Comparison between lead concentrations in leaded fuel after improvements (octane booster and octane plus) treatment.

\begin{tabular}{|c|c|c|c|}
\hline \multirow{2}{*}{$\begin{array}{l}\text { Types of gasoline } \\
\text { (leaded fuel) } \\
\text { Iranian origin }\end{array}$} & $\begin{array}{c}\text { Concentration of } \mathrm{Pb} \\
\mathrm{mg} / \mathrm{L}\end{array}$ & \multirow{2}{*}{$\begin{array}{l}\text { Types of gasoline } \\
\text { (leaded fuel) } \\
\text { German origin }\end{array}$} & $\begin{array}{c}\text { Concentration of } \mathrm{Pb} \\
\mathrm{mg} / \mathrm{L}\end{array}$ \\
\hline & Mean \pm S.D. * & & Mean \pm S.D. * \\
\hline $\begin{array}{l}\text { Doura+ octane } \\
\text { booster }\end{array}$ & $7.55 \pm 0.63^{\mathrm{Aa}}$ & Doura+ octane plus & $1.60 \pm 0.56^{\mathrm{Bb}}$ \\
\hline $\begin{array}{c}\text { Latifiya + octane } \\
\text { booster }\end{array}$ & $5.75 \pm 0.63^{\mathrm{Aa}}$ & $\begin{array}{c}\text { Latifiya + octane } \\
\text { plus }\end{array}$ & $1.05 \pm 0.07^{\mathrm{Bb}}$ \\
\hline $\begin{array}{l}\text { Rusafa+ octane } \\
\text { booster }\end{array}$ & $5.20 \pm 0.14^{\mathrm{Aa}}$ & Rusafa + octane plus & $4.50 \pm 4.94^{\mathrm{Aa}}$ \\
\hline
\end{tabular}

*Different uppercase letters: Significant difference $(\mathbf{P} \leq 0.05)$ between means of columns.

*Different lowercase letters: Significant difference $(P \leq 0.05)$ between means of rows.

Table 3-Comparison among mean concentrations of leaded gasoline types and two other fuel improvements

\begin{tabular}{|c|c|c|c|c|c|}
\hline \multirow{2}{*}{$\begin{array}{c}\text { Types of } \\
\text { gasoline } \\
\text { (leaded fuel) }\end{array}$} & $\begin{array}{c}\text { Concentration of } \\
\mathrm{Pb} \mathrm{mg} / \mathrm{L}\end{array}$ & \multirow{2}{*}{$\begin{array}{l}\text { Types of gasoline } \\
\text { (leaded fuel) } \\
\text { Iranian origin }\end{array}$} & $\begin{array}{c}\text { Concentration of } \\
\mathrm{Pb} \mathrm{mg} / \mathrm{L}\end{array}$ & \multirow{2}{*}{$\begin{array}{c}\text { Types of } \\
\text { gasoline } \\
\text { (leaded fuel) } \\
\text { German origin }\end{array}$} & $\begin{array}{c}\text { Concentration of } \\
\mathrm{Pb} \mathrm{mg} / \mathrm{L}\end{array}$ \\
\hline & Mean \pm S.D. & & Mean \pm S.D. & & Mean \pm S.D. \\
\hline Al. Doura & $100.00 \pm 14.14^{\mathrm{Aa}}$ & $\begin{array}{l}\text { Doura+ octane } \\
\text { booster }\end{array}$ & $7.55 \pm 0.63^{\mathrm{Ac}}$ & $\begin{array}{c}\text { Doura+ octane } \\
\text { plus }\end{array}$ & $1.60 \pm 0.56{ }^{\mathrm{Ad}}$ \\
\hline Latifiya & $105.00 \pm 7.07^{\mathrm{Aa}}$ & $\begin{array}{c}\text { Latifiya + octane } \\
\text { booster }\end{array}$ & $5.75 \pm 0.63^{\mathrm{Ac}}$ & $\begin{array}{l}\text { Latifiya + } \\
\text { octane plus }\end{array}$ & $1.05 \pm 0.077^{\mathrm{Ad}}$ \\
\hline Al. Rusafa & $55.00 \pm 7.07^{\mathrm{Ab}}$ & $\begin{array}{l}\text { Rusafa+ octane } \\
\text { booster }\end{array}$ & $5.20 \pm 0.14^{\mathrm{Ac}}$ & $\begin{array}{c}\text { Rusafa }+ \\
\text { octane plus }\end{array}$ & $4.50 \pm 4.94^{\mathrm{Ac}}$ \\
\hline
\end{tabular}

*Different uppercase letters: Significant difference $(\mathbf{P} \leq \mathbf{0 . 0 5})$ between means of columns.

*Different lowercase letters: Significant difference $(P \leq 0.05)$ between means of rows.

Table 4-Lead emissions $\left(\mu \mathrm{g}\right.$ Lead $\left.\mathrm{m}^{-3}\right)$ from different vehicles in Baghdad

\begin{tabular}{|cc|c|c|}
\hline \multicolumn{2}{|c|}{ Vehicle type } & Register number & $\begin{array}{c}\text { Lead amount } \\
{\boldsymbol{\mu g ~ L e a d ~} \text { }^{-3}}^{-1}\end{array}$ \\
\hline a) & Private cars & 3500000 & 1837.7 \\
\hline b) & Taxis & 1000000 & 1575 \\
\hline c) & Motors / Scooters & 130000 & 15.2 \\
\hline d) & Buses and Trucks & 1300000 & 13.3 \\
\hline \multicolumn{2}{|c|}{ Total } & 5930000 & 3426 \\
\hline
\end{tabular}

The current study also compared lead emissions from different numbers of various types of vehicles in Baghdad (Table-4).Vehicles from groups a, b and c generally used leaded gasoline type with a mean concentration of $105 \mathrm{mg} / \mathrm{L}$, whereas vehicles from group $\mathrm{d}$ used gasoil with a lead concentration of $2.05 \mathrm{mg} / \mathrm{L}$. According to the equation mentioned previously and trip adjustment for each type, fuel efficiency (E), this value for vehicles of groups a and b was $10 \mathrm{Km}$ per liter with an average driving distance (D) that reached to 50 and $150 \mathrm{Km}$ per day, respectively. 
Motorcycles/scooters fuel efficiency (E) was $18 \mathrm{Km}$ per liter with aD value of about $20 \mathrm{Km}$ per day. The $\mathrm{D}$ value for vehicles of group $\mathrm{d}$ was assumed as $60 \mathrm{Km}$ per day in internal roads with the $\mathrm{E}$ variable reached to $12 \mathrm{Km}$ per liter.

The results in Table-4 indicated a high total concentration of lead emitted from tail pipe exhauster of different vehicles $\left(3426 \mu \mathrm{g}\right.$ lead $\left.{ }^{-3}\right)$ which is more than the acceptable limit of WHO (1.30-1.37 $\mu \mathrm{g}$ lead $\mathrm{m}^{-3}$ ) for heavy traffic cities [22]. The reason behind this elevation was the increased number of vehicles and the consecutive checkpoints scattered on roads.

Depending on global statistics, anthropogenic activitiesare responsible for $96 \%$ of ambient lead emissions, which was recently listed within the criteria of air quality (10). Air-born lead attached with fine particulate matter can be attributed to leaded gasoline as the main contributor to increased concentration in the atmosphere, which was synchronized with an increase in numbers of motor vehicles after 2003.

\section{Conclusions}

The determination of lead in different types of gasoline and gasoil was a valuable approach, as engines showed consumption of a large amount of fuel which was reported to be a major contributor to urban air pollution and ultimately to threatening human health. This study represented an attempt to evaluate the values of lead in various fuels widely consumed by automobiles in Baghdad city. Most of the results in this study are within allowable levels proposed by the WHO, and the influence of gasoline improvements was also determined. Moreover, the amount of lead emitted from various types of vehicles was incorporated.

\section{References}

1. Seema Tiwari, I.P. and TripathiTiwari, H.L. 2014.Blood lead level - a review. International Journal of Scientific Engineering and Technology. 3(4): 330-333.

2. Al-Rudainy, L.A. 2010. Blood lead level among fuel stations workers. Oman Med. J. 25(3): 208211.

3. Fewtrell, L., Kaufmann, R. and Press-Ustun.2003. Lead: assessing the environmental burden of disease at national and local levels. Geneva, World Health Organization. Environmental Burden of disease Series, No.2. p.65.

4. Rahbar, M.H.,White, F., Agboatwalla, M., Hozhabri, S. and Luby, S. 2002.Factors associated with elevated blood lead concentrations in children in Karachi, Pakistan. Bull World Health Organ. 80 (10): $1-9$.

5. Tayrab, E.; Abdelrahman, N. and Tirab, A.K. 2014. Blood lead level among fuel station workers at Khartoum city. American Journal of Research Communication. 2(6): 74-82.

6. Billick, I.H.;Curran,A.S. and Shier,D.R. 1980. Relation of pediatric blood lead levels to lead in gasoline. Environmental Health Perspectives. 34: 213-217.

7. California Air Resources Board.1997. Proposed identification of inorganic lead as a toxic air contaminant. Stationary Source Division, part A, Health Assessment.pp.151.

8. The Manufacture of Emission Controls Association (MECA).1998. The case for banning lead in gasoline.pp:1-35.

9. Wang, S.Q. and Zhang, J.L. 2006.Blood lead levels in children, China. Environmental Research. 101: $412-418$.

10. Xu, H.M., Cao, J.J., Ho, K.F., Ding, H., Han, Y.M., Wang, G.H., Chow, J.C., Watson,J.G., Kol, S.D., Qiang, J. and Li, W.T. 2012.Lead concentrations in fine particulate matter after the phasing out of leaded gasoline in Xi'an, China. Atmospheric environment. 46: 217-224.

11. Mohammed, Q.Y., Taher, S.R. and Al-Jubury, H. 2015. Determination of lead in gasoline by extraction and titration at Kurdistan Region-Iraq. American I.J. 2(2): 153-159.

12. Yang, W., Casey, J.F. and Gao, Y. 2017. A new sample preparation method for crude or fuel oils by mineralization utilizing single reaction chamber microwave for broader multi-element analysis by ICP techniques. Fuel. 206: 64-79.

13. Ryan, A. 2010. Determination of lead in unleaded gasoline on liberty series II ICP-OES with the axially-viewed plasma. Agilent Technologies. ICPES-22: 1-3.

14. Al-Mutaz, I.S. and Furiji, R.N. 2001. Protection of unleaded in Riyadh oil refinery presented at $6^{\text {th }}$ world congress of chemical engineering, Melbourne, Australia.pp.23-27.

15. Thomas, V.M. 1995. The elimination of lead in gasoline. Annu.Rev.Energy Environ. 20: 301-324. 
16. New York State Department of Environmental Conservation, NYS-DEC report. 2016. Annual New York State Air Quality Report, Ambient System, New York.pp.54.

17. Parekh, P.P., Khwaja, H.A., Khan, A.R., Naqvi, R.R., Malik, A., Khan, K. and Hussain,G. 2002.Lead content of petrol and diesel and its assessment in an urban environment. Environmental Monitoring and Assessment.74: 255-262.

18. Duyck, C., Miekeley, N., Da Silveira, C.I.P., Campos, R.C. and Grinberg, P. 2007. The determination of trace elements in crude oil and its heavy fractions by atomic spectrometry.Spectrochim Acta. Part B. 62: 939-951.

19. Khuhawar, M.Y., Mirza, M.A. and Jahangir, T.M. 2012.Determination of metal ions in ions in crude oils. INTECH .P.122-144.

20. Murley, L. 1995. Clean air around the world. International Union of Air Pollution Prevention Association, 3th edition, Brighton.pp.402.

21. Magda, L. 1998. Phasing out lead from gasoline. World wide Experience and Policy Implications. Pollution Management Series. World Bank Technical. P: 397.

22. World Health Organization (WHO).2000.Air quality guidelines for Europe. WHO Regional Publication, European Series No.91, 2nd edition .Netherland.pp.149. 